\title{
PENINGKATAN KAPASITAS INSTALASI PENGOLAHAN AIR LIMBAH DOMESTIK PT AJINOMOTO INDONESIA
}

\author{
Setiyono dan Yosep Widi Nugraha \\ Pusat Teknologi Lingkungan, BPPT, Kawasan Puspiptek, Tangerang Selatan, 15314, Indonesia \\ Email: setiyono@bppt.go.id
}

\begin{abstract}
Abstrak
PT Ajinomoto Indonesia merupakan salah satu perusahaan yang bekerja di bidang industri makanan dan berkantor pusat di Jalan Leksda Yos Sudarso No 77-78 Jakarta. Pada tahun 2017 aktivitas kegiatan perkantoran ini meningkat dengan penambahan karyawan dan fasilitas kantin intern, sehingga jumlah limbah domestik yang dihasilkan dari perkantoran ini juga meningkat. Peningkatan jumlah air limbah domestik perlu diantisipasi dengan melakukan peningkatan kapasitas olah IPAL yang ada serta perlu adanya unit pre treatment untuk mengelola limbah kantin. Sistem pretreatment ini meliputi unit oil trap dan bioreaktor anaerobik dengan kapasitas total $10 \mathrm{~m}^{3} /$ hari. Dengan adanya upgrade ini, sistem IPAL dilakukan start-up ulang dan monitoring harian terhadap hasil outlet IPAL PT Ajinomoto Indonesia sampai seluruh sistem dapat berjalan optimal dan hasil IPAL dapat memenuhi baku mutu buangan air limbah domestik yang dipersyaratkan.
\end{abstract}

Kata kunci : air limbah domestik, peningkatan kapasitas IPAL, baku mutu

\section{UPGRADE CAPACITY OF DOMESTIC WASTE WATER TREATMENT PLANT PT AJINOMOTO INDONESIA}

\author{
Setiyono dan Yosep Widi Nugraha \\ Center for Environmental Technology, BPPT, Puspiptek Area, South Tangerang, 15314, Indonesia \\ Email: setiyono@bppt.go.id
}

\begin{abstract}
PT Ajinomoto Indonesia is one of the companies working in the food industry and headquartered at Jalan Leksda Yos Sudarso No. 77-78 Jakarta. In 2017 this office activity increased with the addition of employees and internal canteen facilities, so that the amount of domestic waste generated from these offices also increased. The increase in the amount of domestic wastewater needs to be anticipated by increasing the capacity of the existing WWTP processing and the need for a pre-treatment unit to manage canteen waste. This pretreatment system includes an oil trap and anaerobic bioreactor units with a total capacity of $10 \mathrm{~m} 3$ / day. With this upgrade, the IPAL system will be restarted and monitored daily on the results of PT Ajinomoto Indonesia's WWTP outlet until the entire system can run optimally and the IPAL results can meet the required domestic wastewater discharge standards.
\end{abstract}

Keywords : domestic wastewater, upgrade capacity WWTP, domestic wastewater discharge standards.

\section{PENDAHULUAN}

\subsection{Latar Belakang}

Secara garis besar air limbah yang dihasilkan dari aktifitas manusia dapat digolongkan menjadi 2 jenis, yaitu air limbah industri dan air limbah domestik. Air limbah industri adalah air limbah yang dihasilkan dari proses produksi yang ada di kegiatan suatu industri manufaktur atau pabrik. Sedangkan air limbah domestik adalah air limbah yang dihasilkan dari aktifitas manusia sehari-hari meliputi dari toilet, dapur dan kantin, kamar mandi dan air pencucian pakaian.

Air limbah dari industri maupun domestik sebelum dibuang harus dilakukan proses pengolahan terlebih dahulu dan cara pengolahannya pun perlu disesuaikan dengan karakteristik dari polutan yang ada pada limbah tersebut. Pengolahan air limbah bertujuan untuk menghilangkan parameter pencemar yang ada di dalam air limbah sampai batas yang diperbolehkan untuk dibuang ke badan air sesuai dengan syarat baku mutu yang diijinkan. 
Jumlah air buangan secara keseluruhan di DKI Jakarta diperkirakan sebesar 1.316.113 $\mathrm{m}^{3} /$ hari yakni untuk air buangan domestik 1.038.205 $\mathrm{m}^{3} /$ hari, buangan perkantoran dan daerah komersial $448.933 \mathrm{~m}^{3} /$ hari dan buangan industri $105.437 \mathrm{~m}^{3} /$ hari. Perkiraan jumlah air limbah di wilayah DKI jakarta secara lengkap seperti terlihat pada Tabel 1, sedangkan untuk perkiraan beban polusi ditunjukkan pada Tabel 2 . Dari tabel tersebut dapat diketahui bahwa untuk wilayah Jakarta, dilihat dari segi jumlah, air limbah domestik (rumah tangga) memberikan kontribusi terhadap pencemaran air sekitar $75 \%$, air limbah perkantoran dan daerah komersial 15\%, dan air limbah industri hanya sekitar 10\%. Sedangkan dilihat dari beban polutan organiknya, air limbah rumah tangga sekitar $70 \%$, air limbah perkantoran $14 \%$, dan air limbah industri memberikan kontribusi $16 \%$. Dengan demikan air limbah rumah tangga dan air limbah perkantoran adalah penyumbang yang terbesar terhadap pencemaran air di wilayah DKI Jakarta.

Tabel 1. Perkiraan jumlah air limbah di wilayah DKI Jakarta Tahun 1987 dan Tahun 2010

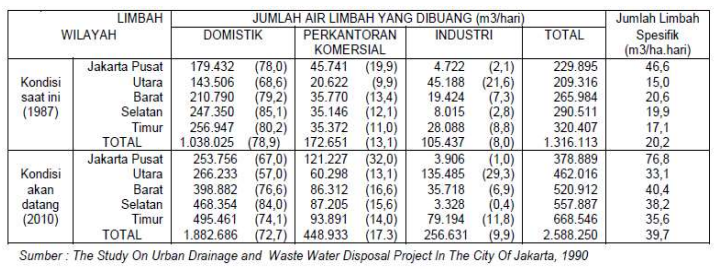

Tabel 2. Perkiraan beban polusi (zat organik) di wilayah DKI Jakarta Tahun 1987 dan Tahun 2010

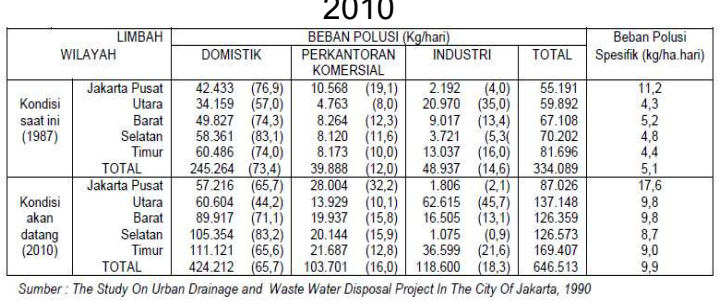

Gedung Perkantoran PT Ajinomoto Indonesia berlokasi di Jl. Leksda Yos Sudarso No 77-78 Sunter, Jakarta, merupakan pusat perkantoran yang mengelola perusahaan dan pengendalian sistem pemasaran produk-produk yang dihasilkan dari perusahaan. Jadi kegiatan yang ada di gedung ini bukan merupakan unit produksi melainkan unit perkantoran yang menjalankan manajemen perusahaan dan pergudangan stok hasil produksi. Limbah yang dihasilkan dari Gedung ini adalah limbah domestik dari aktifitas karyawan perusahaan. Gedung perkantoran PT Ajinomoto Indonesia sudah memiliki unit IPAL untuk mengolah limbah domestik tersebut. Saat ini ada penambahan karyawan dan fasilitas kantin baru di Gedung PT Ajinomoto Indonesia.

\subsection{Permasalahan}

Dengan adanya penambahan karyawan dan fasilitas kantin yang baru, akan meningkatkan jumlah limbah domestik yang dihasilkan, sedangkan kapasitas IPAL PT Ajinomoto Indonesia yang tersedia sudah maksimal, sehingga perlu adanya modifikasi/ penambahan unit baru untuk upgrade kapasitas IPAL PT Ajinomoto Indonesia.

IPAL lama PT Ajinomoto Indonesia dirancang berdasarkan Pergub DKI No. 122 tahun 2005 Tentang Pengelolaan Air Limbah Domestik Di Provinsi DKI Jakarta. Saat ini peraturan yang berlaku menggunakan Peraturan Menteri Lingkungan Hidup dan Kehutanan RI Nomor P.68/Menlhk/Setjen/Kum.1/8/2016 Tentang Baku Mutu Air Limbah Domestik sehingga perlu modifikasi dan perawatan IPAL lama agar dapat menghasilkan outlet sesuai dengan peraturan tersebut. Standar baku mutu yang ditetapkan seperti yang ditunjukkan pada Tabel 3 .

Tabel 3. Baku mutu air limbah domestik (sesuai dengan Peraturan Menteri Lingkungan Hidup dan Kehutanan RI Nomor P.68/Menlhk/ Setjen/Kum.1/8/2016 Tentang Baku Mutu Air Limbah Domestik)

\begin{tabular}{lcc}
\hline \multicolumn{1}{c}{ Parameter } & Satuan & $\begin{array}{c}\text { Kadar } \\
\text { Maksimum }\end{array}$ \\
\hline pH & - & $6-9$ \\
\hline BOD & Mg/L & 30 \\
COD & Mg/L & 100 \\
TSS & Mg/L & 30 \\
Minyak dan & Mg/L & 5 \\
Lemak & Mg/L & 10 \\
\hline Amoniak & Jumlah/100mL & 3000 \\
Total Coliform & L/orang/hari & 100 \\
\hline Debit & & \\
\hline Sumber : Permen LHK RI No. P.68/Menlhk/Setjen/Kum.1/8/2016
\end{tabular}

\subsection{Tujuan dan Sasaran}

Tujuan perancangan dan penelitian ini adalah sebagai berikut :

a. Mengevaluasi sumber limbah domestik yang dihasilkan PT Ajinomoto Indonesia

b. Melaksanakan perhitungan kapasitas dan beban IPAL yang akan dilakukan peningkatan sistem (upgrade system)

c. Membuat desain sistem Instalasi Pengolahan Air Limbah (IPAL) domestik, perawatan serta monitoring terhadap hasil upgrade IPAL

Sasaran yang akan dicapai adalah terbangunnya satu unit upgrade IPAL domestik PT Ajinomoto Indonesia yang lengkap dengan unit 
daur ulang yang dapat menghasilkan outlet limbah yang dapat memenuhi standar baku mutu buangan limbah domestik serta air daur ulang yang sesuai dengan standar air bersih air permukaan kelas IV yang peruntukannya dapat digunakan untuk mengairi pertanaman.

\subsection{Metodologi}

Metodologi pelaksanaan kegiatan ini adalah sebagai berikut:

a. Survei lapangan mengenai keadaan IPAL PT Ajinomoto Indonesia meliputi kondisi mekanik dan elektrik peralatan sistem IPAL.

b. Observasi lapangan dan pengambilan datadata sekunder.

c. Pengumpulan data dengan target mendapatkan data - data sebagai berikut:

- Jumlah limbah yang diolah per hari.

- Karakteristik limbah yang dihasilkan.

d. Pengolahan data sekunder dan data primer dengan bantuan perangkat lunak basis data dan statistik kemudian hasilnya dianalisa

e. Perencanaan teknis sistem IPAL \& sistem daur ulang.

f. Pelaksanaan renovasi upgrade IPAL.

g. Start-up operasional IPAL.

h. Monitoring hasil operasional IPAL.

\subsection{Hasil Yang Diharapkan}

Hasil yang diharapkan dari pekerjaan ini adalah sebagai berikut :

a. Meningkatkan kapasitas olah IPAL PT Ajinomoto Indonesia.

b. Terpenuhinya standar kualitas air limbah buangan, sesuai dengan Peraturan Menteri Lingkungan Hidup dan Kehutanan RI Nomor P.68/Menlhk/Setjen/Kum.1/8/2016 Tentang Baku Mutu Air Limbah Domestik

\section{SUMBER LIMBAH PT AJINOMOTO INDONESIA}

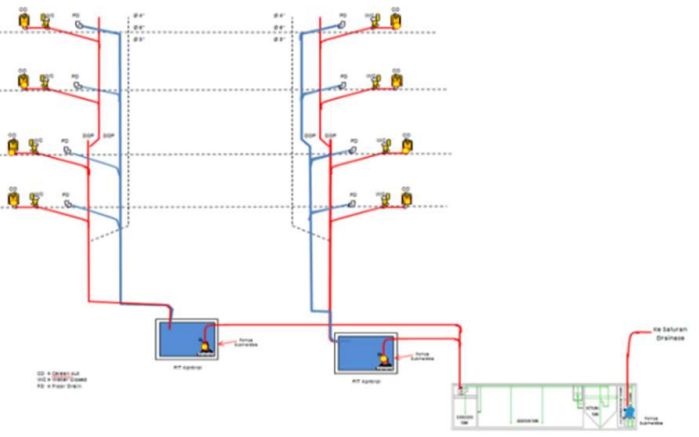

Gambar 1. Sistem perpipaan air limbah toilet PT. Ajinomoto

Saat ini semua air limbah domestik gedung PT. Ajinomoto Indonesia telah diolah di dalam IPAL. Air limbah yang berasal dari berbagai sumber seperti toilet, shoe water, mushola, dapur dan limbah kantin. Air limbah toiltet disalurkan dengan sistem perpipaan tertutup dan terpisahkan dari air hujan menuju ke IPAL terpusat. Secara detail sistem perpipaan toilet yang ada seperti terlihat pada Gambar 1 berikut:

Sumber air limbah yang dihasilkan PT Ajinomoto Indonesia bersumber dari kegiatan di PT Ajinomoto Indonesia. Untuk menentukan kebutuhan air bersih atau jumlah air limbah yang dihasilkan dapat mengacu pada besaran People Equivalent (PE), yaitu tabel kebutuhan air bersih atau jumlah limbah untuk setiap bangunan. Tabel PE ini dapat dilihat seperti pada pada lampiran II Peraturan Gubernur Provinsi DKI Nomor 122 tahun 2005 (lampiran)

Tabel 4. Data pemakaian air di gedung PT Ajinomoto Indonesia

\begin{tabular}{|c|c|c|c|c|}
\hline \multirow{2}{*}{ Bulan } & \multicolumn{2}{|c|}{ Pencatatan Meter Air } & \multirow{2}{*}{$\begin{array}{c}\text { Pemakaian } \\
\text { Air (m3)bulan }\end{array}$} & \multirow{2}{*}{$\begin{array}{l}\text { Pemakaian } \\
\text { Air(m3)/han }\end{array}$} \\
\hline & Awal & Akhir & & \\
\hline $\tan 17$ & 17383 & 18075 & 692 & 27,68 \\
\hline Feb'17 & 18075 & 18799 & 724 & 28,96 \\
\hline Mar'17 & 18799 & 19568 & 769 & 30,76 \\
\hline Apr'17 & 19568 & 20306 & 738 & 29,52 \\
\hline May'17 & 20306 & 21023 & 717 & 28,68 \\
\hline Jun'17 & 21023 & 21761 & 738 & 29,52 \\
\hline Jul'17 & 21761 & 22190 & 429 & 17,16 \\
\hline Aug'17 & 22190 & 22973 & 783 & 31,32 \\
\hline Sep'17 & 22973 & 23862 & 889 & 35,56 \\
\hline Okt'17 & 23862 & 24681 & 819 & 32,76 \\
\hline Nov'17 & 24681 & 25557 & 876 & 35,04 \\
\hline Des'17 & 25557 & 26513 & 956 & 38,24 \\
\hline $\tan 18$ & 26513 & 27270 & 757 & 30,28 \\
\hline Feb'18 & 27270 & 28022 & 752 & 30,08 \\
\hline Mar'18 & 28022 & 28721 & 699 & 27,96 \\
\hline Apr'18 & 28721 & 29384 & 663 & 26,52 \\
\hline \multicolumn{3}{|c|}{ Pemakaian air rata-rata } & 750 & 30 \\
\hline
\end{tabular}

Sumber : Data PT Ajinomoto Indonesia

Untuk menghitung jumlah pemakaian air di PT Ajinomoto Indonesia juga dapat dilakukan berdasarkan besarnya koefisien luas bangunan atau berdasarkan jumlah penghuni bangunan. Untuk bangunan yang baru, perkiraan jumlah air limbah umumnya dilakukan berdasarkan PE untuk tiap-tiap peruntukan dikalikan dengan satuan kapasitas (jumlah orang atau luas lantai atau lainnya).

Perhitungan jumlah pemakaian air bersih berdasarkan jumlah karyawan \& tamu di gedung PT Ajinomoto Indonesia yang berjumlah 500 orang/hari dan peruntukan gedung perkantoran yang standar keperluan air bersih mencapai 50 liter/orang/hari, maka standar jumlah pemakaian air bersih untuk gedung PT Ajinomoto Indonesia adalah sebagai berikut : 
a. Jumlah pegawai $\&$ tamu $=500$ orang/hari.

b. Standar kebutuhan air bersih $=50$ L/orang/hari.

c. Standar jumlah pemakaian air $=500 \mathrm{or} / \mathrm{hr} x$ $50 \mathrm{It} / \mathrm{org} / \mathrm{hr}=25.000$ liter $/$ hari $=625$ m3/bulan (25 hari / bulan).

Disamping menggunakan table PE, untuk mengetahui jumlah kebutuhan air maupun untuk memperkirakan jumlah limbahnya, maka juga dilakukan survei penggunaan air bersih dan jumlah limbah buangan secara langsung. Berdasarkan data pemakaian air bersih selama satu tahun terakhir (hasil pendataan dari rekening listrik), maka telah diketahui jumlah pemakaian air secara bulanan maupun harian.

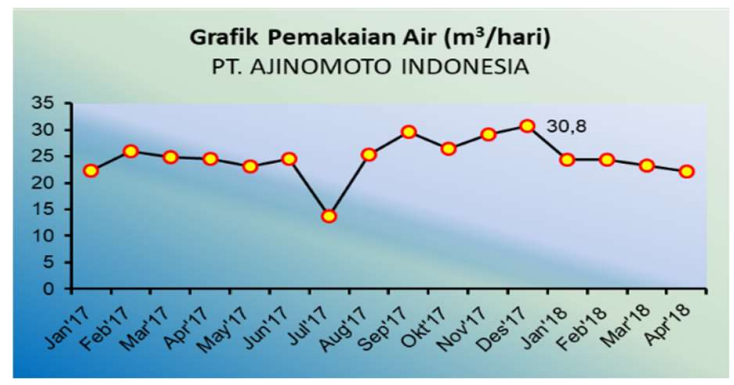

Gambar 2. Grafik pemakaian air PT Ajinomoto Indonesia

Dari data Tabel 4 pemakaian air bersih PT Ajinomoto Indonesia terbesar pada bulan Desember 2017 yaitu $956 \mathrm{~m}^{3} /$ bulan setara dengan $38,24 \mathrm{~m}^{3} /$ hari. Sehingga berdasarkan pemakaian air bulanan, maka diperkirakan limbah yang keluar perhari adalah $80 \% \times 38,24 \mathrm{~m}^{3}=30,59 \mathrm{~m}^{3} /$ hari. Kapasitas IPAL existing adalah $40 \mathrm{~m}^{3} /$ hari sehingga beban kapasitas IPAL masih mencukupi untuk mengolah air limbah yang dihasilkan jika menggunakan perhitungan pendekatan berdasarkan Per. Gub DKI Jakarta No. 122 tahun 2005.

\section{PENGELOLAAN LIMBAH PT AJINOMOTO INDONESIA}

\subsection{Sistem Pengelolaan Limbah PT Ajinomoto Indonesia}

Pengelolaan air limbah PT Ajinomoto Indonesia sebelum dilakukan perancangan baru seperti yang ditunjukkan pada Gambar 3 mengenai neraca air penggunaan air di Gedung PT Ajinomoto Indonesia. Penggunaan air dibagi menjadi 3 bagian yaitu penggunaan air untuk kantin dan dapur, penggunaan air gedung perkantoran (toilet, laboratorium, musholla, janitor) dan penggunaan air siram taman. Limbah dari penggunaan air untuk dapur kantin dan gedung perkantoran diolah ke dalam IPAL PT Ajinomoto Indonesia. Hasil outlet dibuang di saluran umum dan sebagian hasil pengolahan limbah dilakukan reuse untuk siram taman.

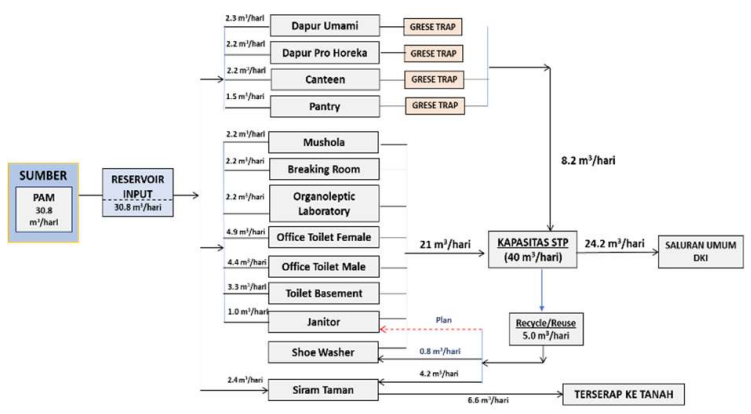

Gambar 3. Neraca air PT Ajinomoto Indonesia

\subsection{Sistem Pengelolaan Limbah PT Ajinomoto Indonesia Desain Baru}

Dalam perencanaannya PT Ajinomoto Indonesia akan menambahkan unit kantin dengan lokasi yang berbeda jauh dari unit IPAL sehingga perlu adanya modifikasi unit pengolahan seperti unit oil trap dan penambahan bioreaktor anaerobik. Seperti sudah dijelaskan di depan, bahwa kapasitas IPAL saat ini adalah $40 \mathrm{~m}^{3} / \mathrm{hari}$, dan akan ada penambahan jumlah limbah dari kantin sekitar 7 hingga $10 \mathrm{~m}^{3} /$ hari. Karena limbah kantin ini banyak mengandung minyak dan bahan organik lainnya maka dikawatirkan akan menambah beban di dalam reaktor IPAL yang ada saat ini. Lokasi kantin juga akan dipindahkan dari lokasi yang ada saat ini. Karena adanya pemindahan lokasi kantin dan peningkatan jumlah pengguna kantin, sehingga akan menambah jumlah limbah yang bersumber dari kantin ini, maka perlu dibuatkan bak oil trap yang baru untuk menggantikan oil trap lama.

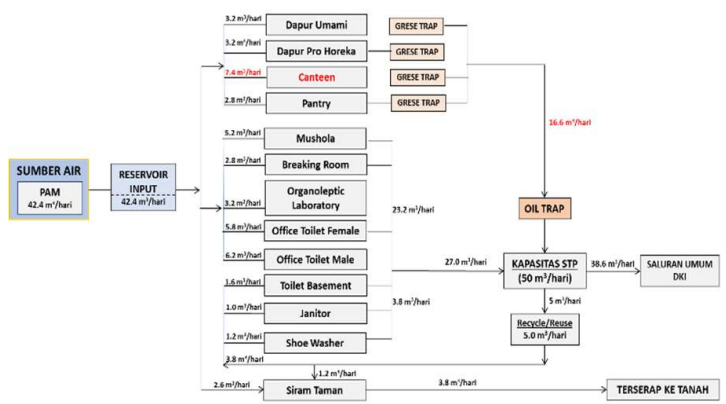

Gambar 4. Neraca air perencanaan IPAL PT Ajinomoto Indonesia

Saat ini jumlah pegawai di PT. Ajinomoto Sunter sebanyak 350 orang. Jika semua pegawai akan difasilitasi di kantin tersebut maka perkiraan jumlah limbah yang bersumber dari kantin sebesar 350 org x 21 L/or.hr = 7.350 L/hari. Jadi kapasitas oil trap ini akan dibuat untuk dapat memproses limbah sebesar 7.350 L/hari. 


\section{PROSES PENGOLAHAN AIR LIMBAH PT AJINOMOTO INDONESIA}

Untuk mengolah air limbah yang mengandung polutan senyawa organik umumnya menggunakan proses biologis (biological process). $\mathrm{Di}$ dalam proses biologi, mikro organisme menggunakan senyawa polutan organik yang ada di dalam air limbah sebagai sumber makanan dan akan dikonversi menjadi senyawa yang lebih sederhana dan tidak berbahaya misalnya menjadi air dan karbon dioksida serta menjadi sel-sel biologis (biomass). Oleh karena di dalam air limbah mengandung bermacam-macam jenis polutan zat organik dan juga mengandung bebagai macam varietas mikro organisme, agar pengolahan air limbah dapat berjalan dengan sempurna diperlukan kultur campuran mikro organisme untuk menguraikan polutan organik yang ada di dalam air limbah.

Secara garis besar ada lima grup proses pengolahan yakni proses aerobik, proses anoxic, proses anaerobik, proses kombinasi aerobik, anoxic dan anaerobik, dan proses dengan lagoon atau kolam. Di dalam aplikasinya, umumnya digunakan untuk berbagai tujuan antara lain :

a. Untuk menghilangkan senyawa organik yang ada di dalam air limbah yang biasanya diukur sebagi biological oxygen demand (BOD), Total karbon organik (TOD), chemical oxygen demand (COD).

b. Untuk proses nitrifikasi.

c. Dentrifikasi.

d. Penghilangan senyawa phospor.

e. Untuk stabilisasi air limbah.

Proses pengolahan limbah domestik PT. Ajinomoto Indonesia menerapkan teknologi lumpur aktif yang dikombinasikan dengan teknologi biofilter dan dilengkapi dengan sistem re-use. IPAL yang terpasang saat ini mempunyai kapasitas olah sebesar $40 \mathrm{~m}^{3} /$ hari. Semua limbah domestik diolah dalam satu IPAL terpusat ini.

Diagram alir proses pengolahan limbah sebelum upgrade dapat dilihat seperti pada Gambar 5 sebagai berikut :

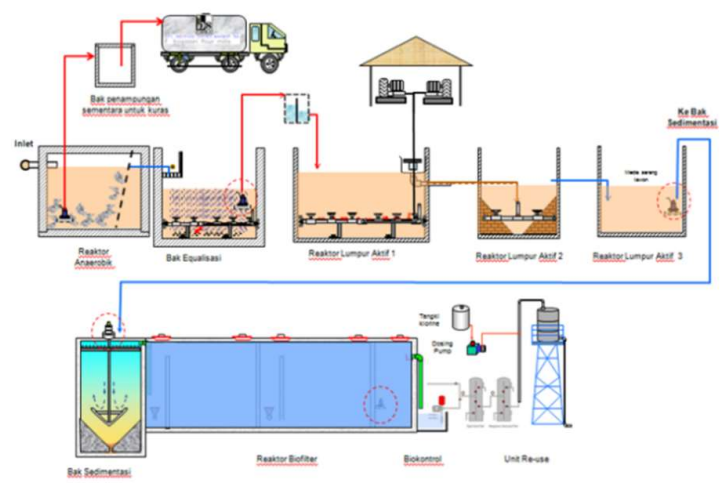

Gambar 5. Diagram alir sistem pengolahan air limbah PT Ajinomoto Indonesia Jakarta

\section{DESAIN PENINGKATAN KAPASITAS, MODIFIKASI DAN PERAWATAN PROSES PENGOLAHAN AIR LIMBAH PT AJINOMOTO INDONESIA}

Dasar desain dan sasaran output air limbah olahan dari IPAL ini juga mengacu pada Pergub DKI No. 122 tahun 2005. Saat ini standar air olahan yang diberlakukan di DKI Jakarta tidak lagi menggunakan Pergub tersebut, tetapi menggunakan dasar Permen LHK RI Nomor P.68/Menlhk/Setjen/Kum.1/8/2016 tentang Baku Mutu Air Limbah Domestik.

Dengan adanya beberapa perubahan ini, output air limbah dari IPAL itu harus dapat memenuhi standar yang berlaku, maka diperlukan adanya perawatan dan modifikasi yang sesuai dengan teknologi proses yang sudah ada di IPAL domestik PT. Ajinomoto Indonesia.

Adanya perkembangan dan perubahan jumlah sumber air limbah maka perancangan desain Instalasi Pengolahan Air Limbah PT Ajinomoto Indonesia juga mengalami perubahan meliputi penambahan kapasitas IPAL dengan adanya penambahan oil trap dan reaktor biofilter anaerob untuk treatment air limbah yang dihasilkan dari kegiatan kantin. Diagram alir desain Instalasi Pengolahan Air Limbah PT Ajinomoto Indonesia dapat dilihat pada Gambar 6.

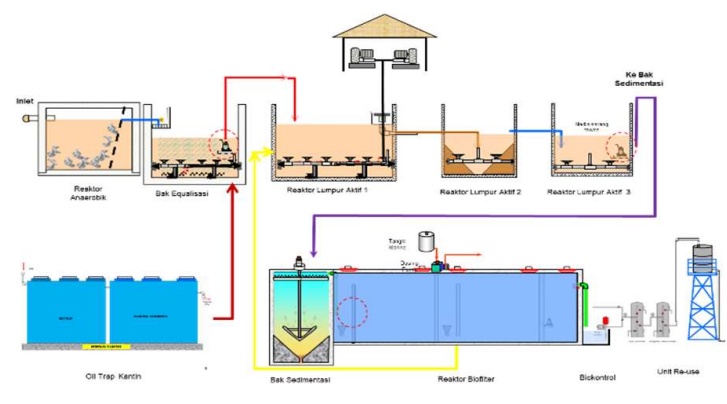

Gambar 6. Diagram alir IPAL PT Ajinomoto Indonesia

Dengan adanya penambahan oil trap dan reaktor anaerobik yang baru akan meningkatkan kapasitas IPAL PT Ajinomoto Indonesia menjadi $50 \mathrm{~m}^{3} / \mathrm{hari}$. Di dalam pengelolaan penggunaan air terdapat perubahan di dalam penggunaan air reuse yaitu selain digunakan untuk siram tanaman air reuse juga digunakan untuk toilet basement, janitor dan shoe water.

\subsection{Penambahan Unit Oil Trap}

Tujuan dari pemisahan minyak adalah untuk menghilangkan minyak dan senyawa hidrokarbon lainnya di dalam proses emulsi mekanik, karena kandungan minyak ini dapat mengganggu proses pengolahan air limbah dalam biofilter. Air yang dihasilkan harus bebas minyak 
sehingga proses biofilter dapat berjalan dengan sempurna efektif dan efisien. Pemisahan minyak dilakukan tanpa adanya penambahan bahan kimia, tetapi hanya dilakukan dengan cara gravitasi alami, dimana cairan minyak naik dengan kecepatan ke atas yang ada dibatasi oleh berat jenisnya (specific gravity).

Berdasarkan hasil evaluasi yang telah dilakukan, maka dapat diketahui bahwa sistem pengelolaan limbah yang ada saat ini belum dapat memenuhi standar, sehingga air buangan yang dari proses produksi ini belum dapat memenuhi standar baku mutu air limbah buangan. Hal ini disebabkan karena oil trap yang terpasang sudah tidak bekerja maksimal. Dalam perancangan ini limbah yang dihasilkan kantin baru akan dialirkan melalui oil trap yang didesain khusus untuk limbah kantin. Oil trap ini berkapasitas $5.7 \mathrm{~m}^{3} / \mathrm{hari}$. Oil trap ini terbuat dari material fiber dimana pemasangan berada atas tanah. Desain oil trap seperti pada Gambar 7.
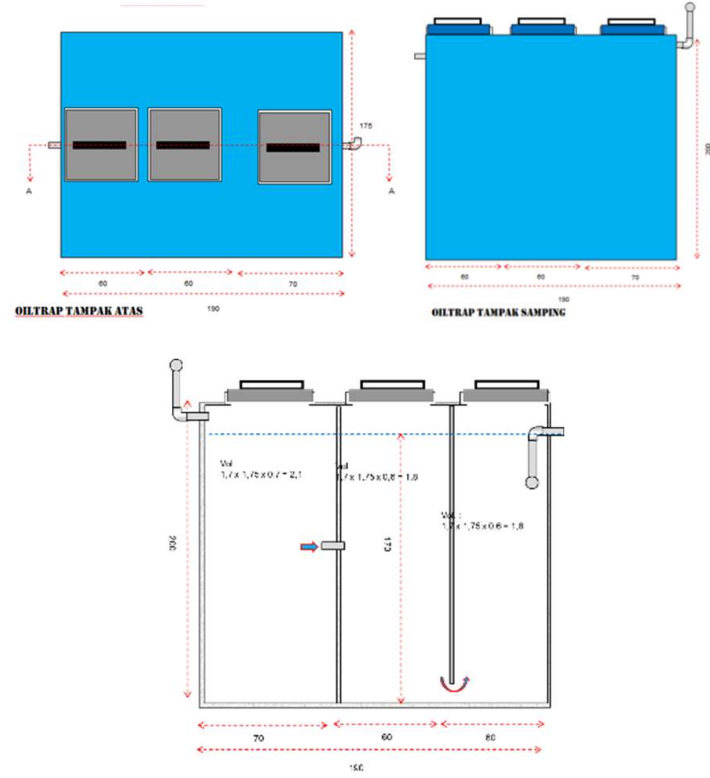

Gambar 7. Desain oil trap PT Ajinomoto Indonesia

\subsection{Penambahan Unit Bioreaktor An-aerobik}

Limbah dari kantin banyak mengandung polutan organik, sehingga untuk menjaga agar IPAL dapat lebih stabil dari yang ada saat ini, maka akan ditambahkan dengan bioreaktor anaerobik baru sebagai unit pre-treatment limbah yang berasal dari kantin. Reaktor yang akan digunakan adalah jenis Bioreaktor Biofilter dengan teknologi media tumbuh mikroba tipe sarang tawon yang sudah banyak diaplikasikan untuk melakukan modifikasi proses dan terbukti dapat memberikan hasil kinerja yang terbaik di berbagai IPAL lainnya yang dimodifikasi dengan teknologi ini.
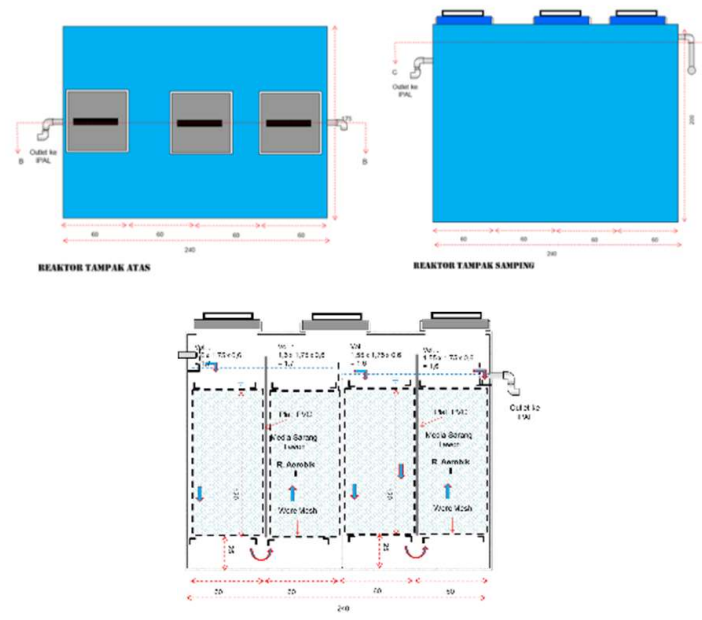

Gambar 8. Desain bioreaktor PT Ajinomoto Indonesia

Penguraian zat-zat organik yang ada dalam air limbah dilakukan oleh bakteri anaerobik atau fakultatif aerobik. Setelah beberapa hari operasi, pada permukaan media filter sarang tawon akan tumbuh lapisan film mikroorganisme. Mikroorganisme inilah yang akan menguraikan zat organik yang ada di dalam limbah.

\subsection{Perawatan Reaktor Biofilter IPAL}

Reaktor biofilter ini berfungsi untuk pengolahan lanjut dan menstabilkan hasil outlet yang ada. Proses pengolahan dengan biofilter anaerob-aerob ini merupakan pengembangan dari proses biofilter anaerob dengan proses aerasi kontak Pengolahan air limbah dengan proses biofilter anaerob-aerob terdiri dari beberapa bagian yakni bak pengendap awal, biofilter anaerob (anoxic), biofilter aerob, dan bak pengendap akhir.

Air limbah dialirkan melalui saringan kasar (bar screen) untuk menyaring sampah yang berukuran besar seperti sampah daun, kertas, plastik dll. Setelah melalui screen air limbah dialirkan ke bak pengendap awal, untuk mengendapkan partikel lumpur, pasir dan kotoran lainnya. Selain sebagai bak pengendapan, juga berfungsi sebagai bak pengontrol aliran, serta bak pengurai senyawa organik yang berbentuk padatan, sludge digestion (pengurai lumpur) dan penampung lumpur.

Air limpasan dari bak pengendap awal selanjutnya dialirkan ke bak kontaktor anaerob dengan arah aliran dari atas ke bawah dan kembali ke atas. Di dalam bak kontaktor anaerob tersebut diisi dengan media dari bahan plastik . Jumlah bak kontaktor anaerob ini bisa dibuat lebih dari satu sesuai dengan kualitas dan jumlah air baku yang akan diolah. Penguraian zat-zat organik yang ada dalam air limbah dilakukan oleh bakteri anaerobik atau fakultatif aerobik Setelah 
beberapa hari operasi, pada permukaan media filter akan tumbuh lapisan film mikroorganisme. Mikroorganisme inilah yang akan menguraikan zat organik yang belum sempat terurai pada bak pengendap

Air limpasan dari bak kontaktor anaerob dialirkan ke bak kontaktor aerob. Di dalam bak kontaktor aerob ini diisi dengan media, pasltik (polyethylene), sambil diaerasi atau dihembus dengan udara sehingga mikroorganisme yang ada akan menguraikan zat organik yang ada dalam air limbah serta tumbuh dan menempel pada permukaan media. Dengan demikian air limbah akan kontak dengan mikroorgainisme yang tersuspensi dalam air maupun yang menempel pada permukaan media yang mana hal tersebut dapat meningkatkan efisiensi penguraian zat organik, deterjen serta mempercepat proses nitrifikasi, sehingga efisiensi penghilangan ammonia menjadi lebih besar. Proses ini sering di namakan Aerasi Kontak (Contact Aeration).

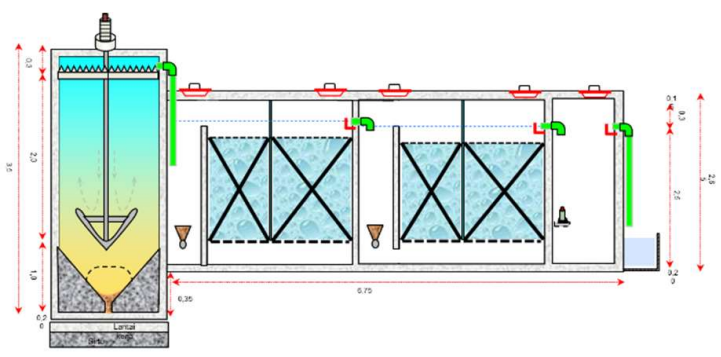

Gambar 9. Biofilter PT Ajinomoto Indonesia

Dari bak aerasi, air dialirkan ke bak pengendap akhir. Di dalam bak ini lumpur aktif yang mengandung massa mikroorganisme diendapkan dan dipompa kembali ke bagian inlet bak aerasi dengan pompa sirkulasi lumpur. Sedangkan air limpasan (over flow) dialirkan ke bak penampung sementara. Dari sini air olahan dipompa untuk difilter dan diberikan kaporit sebagai disinfektan. Air olahan, yakni air yang keluar setelah proses filter ditampung di penampungan sementara untuk selanjutnya ditransfer ke penampungan untuk digunakan kembali sebagai air cucian. Dengan kombinasi proses anaerob dan aerob tersebut selain dapat menurunkan zat organik (BOD, COD), ammonia, deterjen, padatan tersuspensi (SS), phospat dan lainnya.

Reaktor biofilter PT Ajinomoto Indonesia dibangun tahun 2014, kondisi reaktor ini belum dilakukan perawatan (maintenance), dan saat ini di dalam reaktor banyak mengandung lumpur dan sering terangkat ke atas hingga terbawa ke outlet IPAL. Terbawanya lumpur dalam outlet tersebut, mengakibatkan TSS outlet air limbah meningkat hingga tingginya kandungan TSS di dalam outlet.
Untuk mengembalikan fungsi biofilter ini, maka diperlukan perawatan reaktor tersebut.

Perawatan ini meliputi pembersihan reaktor biofilter dari lumpur, pembersihan dan pemilahan media sarang tawon dan modifikasi penambahan sistem drain pembuangan lumpur biofilter.

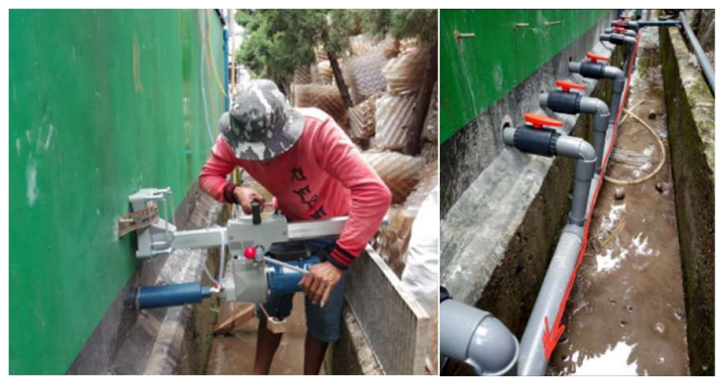

Gambar 10. Modifikasi penambahan sistem drain pembuangan lumpur biofilter

\subsection{Perawatan Bak Sedimentasi dan Penambahan Air Lift}

Bak sedimentasi ini berfungsi untuk mengendap lumpur yang berasal dari reaktor lumpur aktif untuk di-recycle kembali ke dalam reaktor. Sejak dibangun tahun 2014, kondisi bak sedimentasi ini belum dilakukan perawatan, sehingga saat ini sering sekali Lumpur terangkat ke atas, lalu masuk ke dalam reaktor biofilter. Terlepasnya Lumpur ke dalam reaktor biofilter tersebut, mengakibatkan TSS air limbah di dalam reaktor biofilter meningkat hingga keluar bersama outlet air limbah yang mengakibatkan tingginya kandungan TSS di dalam outlet. Untuk mengembalikan fungsi bak sedimentasi ini, maka diperlukan perawatan bak tersebut.

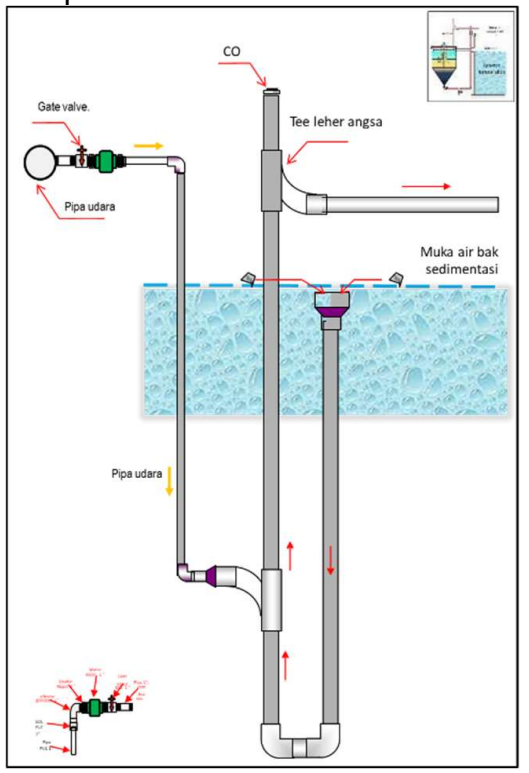

Gambar 11. Sistem air lift bak Sedimentasi IPAL PT Ajinomoto Indonesia 
Air lift merupakan suatu sistem pengambilan lumpur yang terdapat di bagian atas (mengapung) di bak sedimentasi pada unit IPAL PT Ajinomoto Indonesia. Modifikasi penambahan air lift ini dimaksudkan untuk pengendalian lumpur di bak sedimentasi. Air lift menggunakan sistem aliran pipa yang dikoneksikan pada bagian bawah bak sedimentasi dan aliran udara blower akan menarik lumpur yang mengapung dan membuang lumpur kembali ke dalam lumpur aktif. Sistem air lift dapat dilihat pada Gambar 11.

\subsection{Perawatan Sistem Reuse IPAL PT Ajinomoto Indonesia}

Unit reuse ini berfungsi menyaring partikel kasar yang berasal dari outlet IPAL dan hasil oksidasi kalium permanganat atau klorin, termasuk besi dan mangan. Unit filter berbentuk silinder dan terbuat dari bahan fiberglas. Unit ini dilengkapi dengan keran - keran yang berfungsi sebagai pengatur arah aliran, filtrasi atau backwash sehingga untuk proses pencucian balik dapat dilakukan dengan sangat sederhana, yaitu dengan hanya memutar keran tersebut sesuai dengan petunjuknya. Tinggi filter ini mencapai 120 $\mathrm{cm}$ dan berdiameter 12 inchi. Media penyaring yang digunakan berupa pasir silika dan terdiri dari 4 ukuran, yaitu lapisan dasar terdiri dari kerikil dengan diameter $2-3 \mathrm{~cm}$ dan kerikil halus dengan diameter $0,5-1 \mathrm{~cm}, 3-5 \mathrm{~mm}$, dan lapisan penyaring yang terdiri dari lapisan pasir silika dengan diameter 2 - $1 \mathrm{~mm}$ dan pasir silika halus dengan diameter partikel $1-0,5 \mathrm{~mm}$. Unit filter ini juga didesain secara khusus, sehingga memudahkan dalam hal pengoperasiannya dan pemeliharaannya. Dengan dilengkapi oleh 2 (dua) buah water moore, maka penggantian media filter dapat dilakukan dengan mudah.

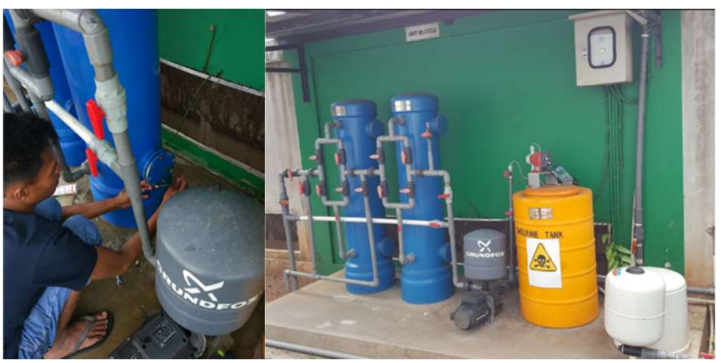

Gambar 12. Perawatan Sistem Reuse IPAL PT Ajinomoto Indonesia

Sampai saat ini, media filter air reuse maupun outlet sudah digunakan selama 3 tahun dan belum pernah dilakukan perawatan (maintenance) maupun penggantian media isian filter tersebut. Dengan demikian diperkirakan bahwa media filter ini sudah jenuh, sehingga tidak dapat lagi menyerap kandungan polutan yang masih tersisa di dalam air yang disaring. Disamiping itu, diperkirakan screen penyaring media yang ada di dalam unit filter telah terlepas/patah, sehingga sewaktu dilakukan backwash filter, media isian yang ada terikut terbawa keluar dari filter.

Rencana perbaikan unit reuse yang akan dilakukan adalah, perbaikan /penggantian screen filter dan penggantian media isian filter. Bahan media penggantian antara lain: batu kerikil, pasir silika, manganese green sand dan karbon aktif.

\subsection{Perawatan dan Modifikasi Sistem Klorinasi Bak Outlet}

Modifikasi sistem klorinasi ini berupa penggantian tabung klorinator yang dibuat dari pipa PVC dan pada bagian ujungnya diberi lubang yang bertujuan agar air hasil olahan dari biofilter bisa masuk, sementara ikan yang bertugas sebagi bioindikator tidak masuk ke dalam saluran pembuangan. Selain itu modifikasi alat tabung klorinator ini dimaksudkan agar larutan klorin yang berada di dalam tabung klorinator tidak masuk ke dalam bak biokontrol sehingga ikan yang ada di dalam bak biokontrol tetap bisa hidup.

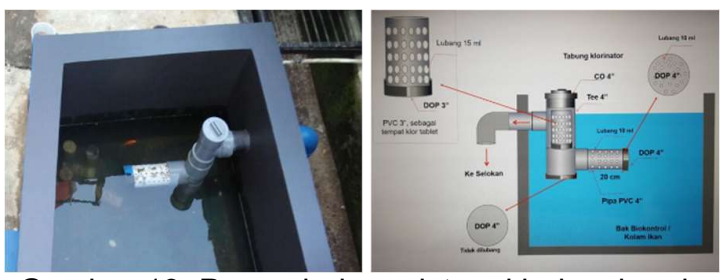

Gambar 13. Penambahan sistem klorinasi pada bak outlet biokontrol

\section{START UP DAN MONITORING HASIL PENGOLAHAN AIR LIMBAH.}

Dengan adanya pekerjaan penambahan unit pretreatment limbah dari kantin (unit oil trap dan unit bioreaktor anaerob) dan perawatan reaktor biofilter, maka perlu dilakukan start-up ulang pada kedua unit tersebut. Untuk mempercepat pekerjaan start-up dan IPAL segera mencapai kondisi stabil, maka diperlukan adanya penambahan bibit mikroba dari luar sistem dan adanya penambahan nutrisi agar mikroba dapat dengan cepat berkembang biak dan IPAL mencapai kondisi operasional yang stabil. Dalam kegiatan start-up dilakukan selama 1 bulan pengoperasian unit IPAL dan dilaksanakan pengamatan harian serta setting peralatan unit IPAL agar IPAL dicapai kondisi yang optimal dan menghasilkan outlet yang memenuhi baku mutu buangan limbah cair domestik sesuai yang dipersyaratkan.

Setelah IPAL dioperasikan dengan diawali start-up operasional, maka diperlukan monitoring hasil untuk melihat kinerja IPAL. Monitoring IPAL juga diperlukan untuk melakukan setting sistem agar IPAL dapat bekerja pada kondisi optimal. Kegiatan monitoring dilaksanakan dengan 
melakukan pengambilan sampel di empat titik yaitu di bak lumpur aktif (LA), bak lumpur recycle (LR), outlet sedimentasi (OS) dan di outlet biofilter (OB). Di setiap pengambilan sampel dilakukan pengamatan visual dan pengukuran $\mathrm{pH}$. Setelah pengambilan sampel dilakukan, sampel dibiarkan selama 15 menit untuk mengamati adanya pengendapan lumpur yang terjadi. Pengendapan lumpur terjadi pada sampel LA dan LR hal ini dikarenakan adanya endapan lumpur yang masih ada dalam bak sedimentasi.

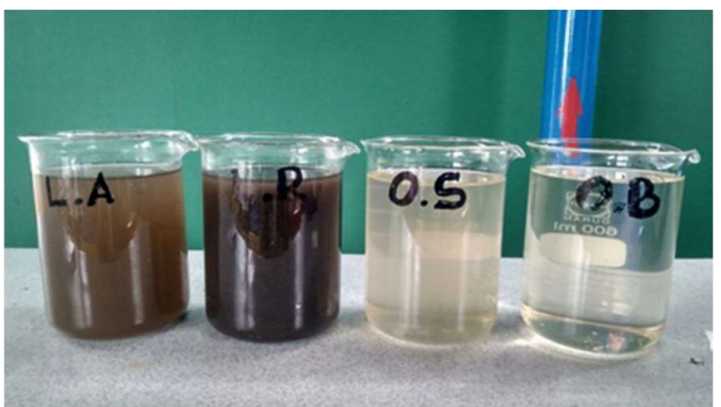

Gambar 14. Sampel yang diambil di empat titik pengambilan sampel

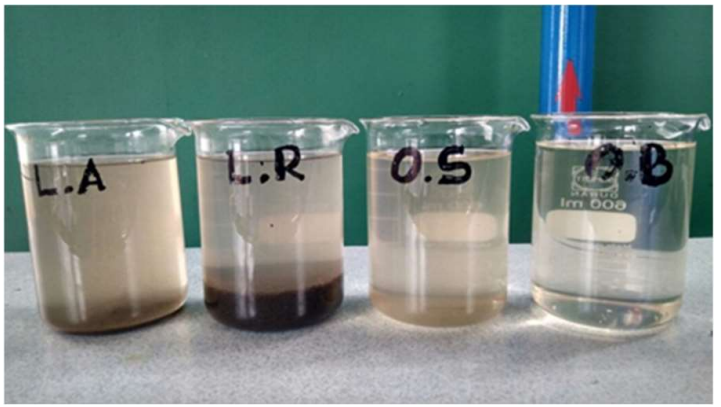

Gambar 15. Kondisi sampel setelah 15 menit

Pengukuran $\mathrm{pH}$ masing-masing sampel dilakukan setiap hari oleh operator selama 2 bulan. Pelaksanaan monitoring $\mathrm{pH}$ ini dilakukan sampai sistem IPAL dapat bekerja dengan stabil dan optimal (2 bulan). Hasil monitoring pengukuran $\mathrm{pH}$ ditampilkan dari Gambar 16 dan 17

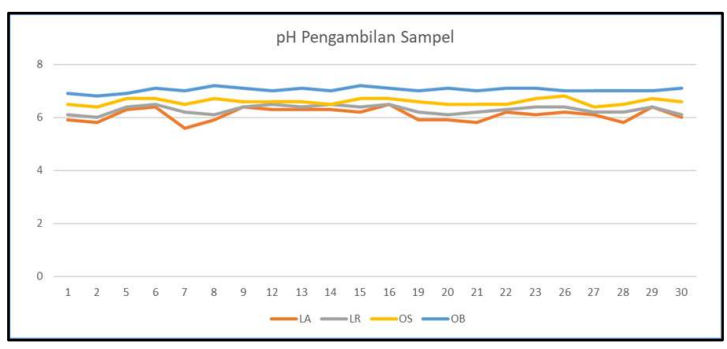

Gambar 16. Grafik pH sampel LA, LR, OS dan OB IPAL PT Ajinomoto bulan Febuari 2018

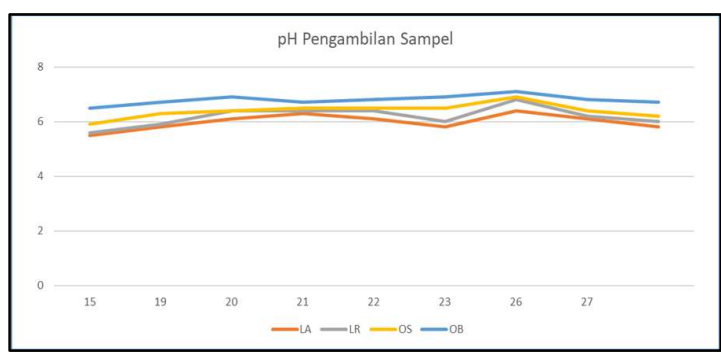

Gambar 17. Grafik pH sampel LA, LR, OS dan OB IPAL PT Ajinomoto bulan Maret 2018

Sampel LA merupakan sampel yang diambil dari bak lumpur aktif, dari hasil pengambilan sampel dan pengukuran $\mathrm{pH}$ didapatkan bahwa $\mathrm{pH}$ sampel LA cukup rendah (asam) hal ini dapat disebabkan oleh air limbah dari kantin bersifat asam. Pengolahan air limbah dengan proses lumpur aktif pada IPAL PT Ajinomoto Indonesia terdiri dari bak pengendap awal (ekualisasi), bak aerasi dan bak pengendap akhir. Desain IPAL PT Ajinomoto Indonesia terdapat tiga unit pengolahan air limbah menggunakan bak lumpur aktir (lihat Gambar 6). Air limbah PT Ajinomoto Indonesia ditampung ke dalam bak ekualisasi yang berfungsi sebagai bak pengatur debit air limbah dan sebagai bak pengendap awal yang dilengkapi dengan saringan kasar untuk memisahkan kotoran ukuran besar. Selanjutnya air limbah dialirkan ke bak aerasi dihembus dengan udara blower sehingga mikroorganisme yang ada akan menguraikan zat organik yang ada dalam air limbah. Energi yang didapatkan dari hasil penguraian zat organik tersebut digunakan oleh mikroorganisme untuk proses pertumbuhannya. Dengan demikian di dalam bak aerasi tersebut akan tumbuh dan berkembang biomassa dalam jumlah yang besar. Biomasa atau mikroorganisme inilah yang akan menguraikan senyawa polutan yang ada di dalam air limbah.

Dari bak aerasi, air limbah hasil olahan bak aerasi dialirkan ke dalam bak pengendap akhir. Di dalam bak ini lumpur aktif yang mengandung massa mikro organisme diendapkan dan dipompa kembali ke bagian inlet bak aerasi dengan pompa sirkulasi lumpur. Pada sistem recycle inilah diambil sampel $\mathrm{LR}$ dimana $\mathrm{pH}$ yang didapatkan sudah mengalami kenaikan (Gambar 16 dan 17). Air limbah hasil outlet bak sedimentasi kemudian diambil sampelnya (OS) pada proses pengendapan ini $\mathrm{pH}$ sampel tidak berbeda jauh dengan kondisi LR karena padatan air limbah yang mengandung mikroorganisme dan endapan lainnya sudah mengendap. Air limbah hasil sedimentasi dialirkan ke dalam bak biofilter, dimana di dalam biofilter inilah terdapat proses aerob dan anaerob. Air limbah hasil olahan biofilter (outlet) dialirkan ke dalam bak biokontrol dan kemudian diambil sampel OB. $\mathrm{pH}$ sampel 
OB mengalami peningkatan dibandingkan dengan proses sebelumnya. Monitoring dilaksanakan setiap hari kerja sampai dengan $\mathrm{pH}$ OB sudah stabil.

Sesuai dengan Peraturan Menteri Lingkungan Hidup dan Kehutanan RI Nomor P.68/Menlhk/Setjen/Kum.1/8/2016 Tentang Baku Mutu Air Limbah Dometik, maka dilakukan uji laboratorium terhadap hasil outlet IPAL PT Ajinomoto Indonesia. Uji Laboratorium dilaksanakan setiap bulan untuk pengendalian baku mutu sesuai dengan yang dipersyaratkan. Hasil uji laboratorium sebagai berikut :

Tabel 5. Hasil uji laboratorium IPAL PT Ajinomoto Indonesia bulan Febuari 2018

\begin{tabular}{lccc}
\hline Parameter & Satuan & $\begin{array}{c}\text { Kadar } \\
\text { Maksimum }\end{array}$ & $\begin{array}{c}\text { Hasil } \\
\text { Outlet }\end{array}$ \\
\hline pH & - & $6-9$ & 8.3 \\
BOD & $\mathrm{Mg} / \mathrm{L}$ & 30 & 3.36 \\
COD & $\mathrm{Mg} / \mathrm{L}$ & 100 & $<40$ \\
TSS & $\mathrm{Mg} / \mathrm{L}$ & 30 & 2.0 \\
$\begin{array}{l}\text { Minyak dan } \\
\text { Lemak }\end{array}$ & $\mathrm{Mg} / \mathrm{L}$ & 5 & 0.69 \\
$\begin{array}{l}\text { Amoniak } \\
\text { Total } \\
\text { Coliform }\end{array}$ & $\mathrm{Mg} / \mathrm{L}$ & 10 & 7.76 \\
\hline
\end{tabular}

Sumber : Hasil Uji laboratorium Oulet IPAL PT Ajinomoto Bulan Febuari 2018 UPT Laboratorium Lingkungan Hidup Daerah

\section{KESIMPULAN}

a. Adanya peningkatan kegiatan pekerjaan PT Ajinomoto Indonesia menjadikan jumlah karyawan menjadi ikut meningkat. Peningkatan kegiatan ini juga meningkatkan jumlah air limbah domestik yang dihasilkan sehingga perlu adanya evaluasi dan peningkatan kinerja sistem IPAL PT Ajinomoto Indonesia.

b. Penambahan fasilitas unit kantin PT Ajinomoto Indonesia menyebabkan air limbah domestik mengalami peningkatan. Limbah kantin merupakan salah satu sumber limbah yang mengandung minyak, sehingga dalam penanganannya diperlukan penambahan unit pretreatment yang berupa oil trap dan bioreaktor anaerobik. Penambahan unit ini dimaksudkan untuk penanganan sumber limbah kantin sebelum masuk ke sistem
IPAL PT Ajinomoto Indonesia. Kapasitas unit pretreatment sebesar $10 \mathrm{~m}^{3} /$ hari.

c. Permasalahan yang terjadi di dalam sistem unit IPAL PT Ajinomoto Indonesia meliputi :

- Beban kapasitas yang tinggi menyebabkan bak sedimentasi kurang bekerja optimal sehingga sebagian lumpur masuk ke dalam biofilter. Permasalahan ini diatasi dengan membuat air lift pada bak sedimentasi dan sistem drain lumpur pada biofilter.

- Sistem klorinasi belum bekerja optimal, sehingga perlu penambahan sistem klorinasi yang dilokasikan pada bak biokontrol.

d. Kegiatan monitoring dilaksanakan setelah start-up sistem IPAL PT Ajinomoto Indonesia yang meliputi :

- Pengambilan sampel harian pada 4 titik pemantauan yaitu LA, LR, OS dan OB

- Pengukuran pH di setiap pengambilan sampel.

- Melakukan uji laboratorium pada saat sistem IPAL PT Ajinomoto Indonesia sudah stabil

\section{DAFTAR PUSTAKA}

1. Said, N.I. (2000). "Pengolahan Air Limbah dengan Proses Biofilter Anaerob-Aerob". Jurnal Teknologi Lingkungan, BPPT. Jakarta.

2. Setiyono, Satmoko Yudo "Panduan Pengelolaan Instalasi Pengolahan Air Limbah Industri Otomotif' BPPT Press 2014.

3. Ir. Nusa Idaman Said, M.Eng, (2005) "Proses Dasar Dalam Pengolahan Limbah Cair"

4. Scherfig, J., and Mosharraf. F., Two-stage backwash system for wastewater filters using primary and final effluent. J. WPCF, 16511657, 1989.

5. Peraturan Menteri Lingkungan Hidup dan Kehutanan RI Nomor P.68/Menlhk /Setjen /Kum.1/8/2016 Tentang Baku Mutu Air Limbah Dometik.

6. Data Sheet Penggunaan Air PDAM PT Ajinomoto Indonesia 2017-2018 


\section{LAMPIRAN 1}

Tabel 6. Besaran Population Equivalen $(\mathrm{Pe})$ untuk perancangan IPAL berdasarkan jenis peruntukan bangunan.

\begin{tabular}{|c|c|c|c|c|c|c|}
\hline No. & $\begin{array}{c}\text { Peruntukan } \\
\text { Bangunan }\end{array}$ & $\begin{array}{l}\text { Pemakaian } \\
\text { Air Bersih }\end{array}$ & $\begin{array}{c}\text { Debit } \\
\text { Air Limbah }\end{array}$ & Satuan & $\mathrm{PE}$ & Acuan \\
\hline 1 & 2 & 3 & 4 & 5 & 6 & 7 \\
\hline 1. & Rumah Mewah & 250 & 200 & Liter/penghuni/hari & 1,67 & $\begin{array}{l}\text { Perancangan dan Pemeliharaan Sistem Plambing, } \\
\text { Soufyan M. Noerbambang dan Takeo Morimura }\end{array}$ \\
\hline 2. & Rumah Biasa & 150 & 120 & Liter/penghuni/hari & 1,00 & Study JICA 1990 (proyeksi 2010) \\
\hline 3. & Apartment & 250 & 200 & Liter/penghuni/hari & 1,67 & $\begin{array}{l}\text { Perancangan dan Pemeliharaan Sistem Plambing, } \\
\text { Soufyan M. Noerbambang dan Takeo Morimura }\end{array}$ \\
\hline 4. & Rumah Susun & 100 & 80 & Liter/penghuni/hari & 0,67 & \\
\hline 5. & Asrama & 120 & 96 & Liter/penghuni/hari & 0,80 & \\
\hline 6. & Klinik / Puskesmas & 3 & 2,7 & Liter/pengunjung/hari & 0,02 & $\begin{array}{l}\text { Perancangan dan Pemeliharaan Sistem Plambing, } \\
\text { Soufyan M. Noerbambang dan Takeo Morimura }\end{array}$ \\
\hline \multirow[t]{3}{*}{7.} & Rumah sakit Mewah & 1000 & 800 & $\begin{array}{l}\text { Liter/jumlah tempat } \\
\text { tidur pasien/hari }\end{array}$ & 6,67 & $\begin{array}{l}\text { Perancangan dan Pemeliharaan Sistem Plambing, } \\
\text { Soufyan M. Noerbambang dan Takeo Morimura }\end{array}$ \\
\hline & Rumah Sakit Menengah & 750 & 600 & $\begin{array}{l}\text { Liter/jumlah tempat } \\
\text { tidur pasien/hari }\end{array}$ & 5,00 & $\begin{array}{l}\text { Perancangan dan Pemeliharaan Sistem Plambing, } \\
\text { Soufyan M. Noerbambang dan Takeo Morimura }\end{array}$ \\
\hline & Rumah Sakit Umum & 425 & 340 & $\begin{array}{l}\text { Liter/jumlah tempat } \\
\text { tidur pasien/hari }\end{array}$ & 2,83 & $\begin{array}{l}\text { Perancangan dan Pemeliharaan Sistem Plambing, } \\
\text { Soufyan M. Noerbambang dan Takeo Morimura }\end{array}$ \\
\hline 8. & Sekolah Dasar & 40 & 32 & Liter/siswa/hari & 0,27 & SNI 03-7065-2005 \\
\hline 9. & SLTP & 50 & 40 & Liter/siswa/hari & 0,33 & SNI 03-7065-2005 \\
\hline 10 & SLTA & 80 & 64 & Liter/siswa/hari & 0,53 & SNI 03-7065-2005 \\
\hline 11 & Perguruan Tinggi & 80 & 64 & Liter/mahasiswa/hari & 0,53 & SNI 03-7065-2005 \\
\hline 12 & $\begin{array}{l}\text { Rumah Toko / Rumah } \\
\text { Kantor }\end{array}$ & 100 & 80 & $\begin{array}{l}\text { Liter/penghuni dan } \\
\text { pegawai/hari }\end{array}$ & 0,67 & SNI 03-7065-2005 \\
\hline 13 & Gedung Kantor & 50 & 40 & Liter/pegawai/hari & 0,33 & SNI 03-7065-2005 \\
\hline 14 & $\begin{array}{l}\text { Toserba (toko serba ada, } \\
\text { mall, department store) }\end{array}$ & 5 & 4,5 & Liter $/ \mathrm{m}^{2}$ luas lantai/hari & 0,04 & SNI 03-7065-2005 \\
\hline 15 & Pabrik / Industri & 50 & 40 & Liter/pegawai/hari & 0,33 & SNI 03-7065-2005 \\
\hline 16 & Stasiun / Terminal & 3 & 2,7 & $\begin{array}{l}\text { Liter/penumpang tiba } \\
\text { dan pergi/hari }\end{array}$ & 0,02 & SNI 03-7065-2005 \\
\hline 17. & Bandara Udara * & 3 & 2,7 & $\begin{array}{c}\text { Liter/penumpang tiba } \\
\text { dan pergi/hari }\end{array}$ & 0,02 & $\begin{array}{l}\text { Perancangan dan Pemeliharaan Sistem Plambing, } \\
\text { Soufyan M. Noerbambang dan Takeo Morimura }\end{array}$ \\
\hline 18 & Restoran & 15 & 13,5 & Liter/kursi/hari & 0,11 & SNI 03-7065-2005 \\
\hline 19 & Gedung Pertunjukan & 10 & 9 & Liter/kursi/hari & 0,08 & SNI 03-7065-2005 \\
\hline 20 & Gedung Bioskop & 10 & 9 & Liter/kursi/hari & 0,08 & SNI 03-7065-2005 \\
\hline 21 & Hotel Melati s/d Bintang 2 & 150 & 120 & Liter/tempat tidur/hari & 1,00 & SNI 03-7065-2005 \\
\hline 22 & Hotel Bintang 3 ke atas & 250 & 200 & Liter/tempat tidur/hari & 1,67 & SNI 03-7065-2005 \\
\hline 23 & Gedung Peribadatan & 5 & 4,5 & $\begin{array}{c}\text { Liter/orang/hari (belum } \\
\text { dengan air wudhu) }\end{array}$ & 0,04 & SNI 03-7065-2005 \\
\hline 24 & Perpustakaan & 25 & 22,5 & $\begin{array}{c}\text { Liter/jmlh. } \\
\text { pengunjung/hari }\end{array}$ & 0,19 & $\begin{array}{l}\text { Perancangan dan Pemeliharaan Sistem Plambing, } \\
\text { Soufyan M. Noerbambang dan Takeo Morimura }\end{array}$ \\
\hline 25 & Bar & 30 & 24 & $\begin{array}{c}\text { Liter/jmlh. } \\
\text { pengunjung/hari }\end{array}$ & 0,20 & $\begin{array}{l}\text { Perancangan dan Pemeliharaan Sistem Plambing, } \\
\text { Soufyan M. Noerbambang dan Takeo Morimura }\end{array}$ \\
\hline 26 & Perkumpulan Sosial & 30 & 27 & $\begin{array}{c}\text { Liter/jmlh. } \\
\text { pengunjung/hari }\end{array}$ & 0,23 & $\begin{array}{l}\text { Perancangan dan Pemeliharaan Sistem Plambing, } \\
\text { Soufyan M. Noerbambang dan Takeo Morimura }\end{array}$ \\
\hline 27 & Klab Malam & 235 & 188 & Liter/kursi/hari & 1,57 & $\begin{array}{l}\text { Perancangan dan Pemeliharaan Sistem Plambing, } \\
\text { Soufyan M. Noerbambang dan Takeo Morimura }\end{array}$ \\
\hline 28 & Gedung Pertemuan & 25 & 20 & Liter/kursi/hari & 0,17 & $\begin{array}{l}\text { Perancangan dan Pemeliharaan Sistem Plambing, } \\
\text { Soufyan M. Noerbambang dan Takeo Morimura }\end{array}$ \\
\hline 29 & Laboratorium & 150 & 120 & Liter/staf/hari & 1,00 & $\begin{array}{l}\text { Perancangan dan Pemeliharaan Sistem Plambing, } \\
\text { Soufyan M. Noerbambang dan Takeo Morimura }\end{array}$ \\
\hline 30 & $\begin{array}{l}\text { Pasar Tradisional / } \\
\text { Modern }\end{array}$ & 40 & 36 & Liter/kios/hari & 0,30 & $\begin{array}{l}\text { Perancangan dan Pemeliharaan Sistem Plambing, } \\
\text { Soufyan M. Noerbambang dan Takeo Morimura }\end{array}$ \\
\hline
\end{tabular}

Keterangan :

* Untuk pelayanan publik

- Perhitungan menggunakan pendekatan PE hanya dipakai apabila tidak ada data aktual jumlah pemakaian air bersih per hari. 


\section{LAMPIRAN 2}

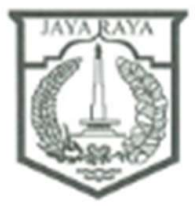

PEMERINTAH PROVINSI DAERAH KHUSUS IBUKOTA JAKARTA DINAS LINGKUNGAN HIDUP

\section{UPT LABORATORIUM LINGKUNGAN HIDUP DAERAH}

Jl. Casablanca Kav.1 Kuningan Telp. 5209651-5209653, Fax.5209643, e-mail: labblingkungan@jakarta.go.id JAKARTA

Kode Pos : 12950

\section{LAPORAN HASIL UJI}

\begin{tabular}{|c|c|}
\hline Nomor Contoh & : 1697 - 1696/LAB. 1LD - LCMI/2018 \\
\hline Contoh Dari & : PT. AJINOMOTO INDONESIA \\
\hline Alamat & : Jalan Laksda Yos Sudarso No $77-78$ Sunter, Jakarta \\
\hline Jenis IndustriKegiatan & : Perkantoran \\
\hline Tanggal Penerimaan Contch & : 22 Februari 2018 \\
\hline Tanggal Pengujian & : 22 Februari 2018 - 1 Maret 2018 \\
\hline Badan Air Penerima & :- \\
\hline Jenis Contoh & : Arr Limbah \\
\hline Tpe Lokasi & : Inlet/Outlet \\
\hline
\end{tabular}

\begin{tabular}{|c|c|c|c|c|c|c|}
\hline \multirow{2}{*}{ No } & \multirow{2}{*}{ Parameter } & \multirow{2}{*}{ Satuan } & \multicolumn{2}{|c|}{ Hasil Uj } & \multirow{2}{*}{ Kadar Maksimum } & \multirow{2}{*}{ Metoda } \\
\hline & & & 1697 & 1698 & & \\
\hline 1 & $\mathrm{pH}$ & & 7.7 & 83 & 6.9 & SNI 06-6989.11-2004 \\
\hline 2 & Zat Padat Tersuspensi & $\mathrm{mgll}$ & 245.0 & 2.0 & 30 & Spektrofotometri \\
\hline 3 & Ammonia & $\mathrm{mgh}$ & 48.24 & 7.76 & 10 & No. 41/KM (Segmented Flow Analysis) \\
\hline 4 & Minyck dan Lemak & $\mathrm{mgl} / \mathrm{L}$ & 2.59 & 0.69 & 5 & Speitrofotometri \\
\hline 5 & COD (Dichromat) & $\mathrm{mgll}$ & 413.93 & $<40.0$ & 100 & SNI 6989.73:2009 (Titrimetr) \\
\hline 6 & $B O 0\left(20^{\circ} \mathrm{C}, 5\right.$ hai $)$ & $\mathrm{mgl}$ & 56.64 & 3.36 & 30 & SNI 6009.722009 \\
\hline 7 & Total Coliform & Juntah $100 \mathrm{~mL}$ & $\cdot$ & 0 & 3000 & No 40/KM (Petrifim) \\
\hline
\end{tabular}

Keterancan:

1097 eirien

1698 - Cutet

-) Tidak danaiso

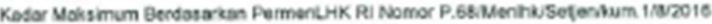

Parsmeter yanp lercetak vebel ielon dokiroditasi alah KAN

Jakarta, 7 maret 2018

Kepala UPT Laboratorium Lingkungan Hidup Daerah

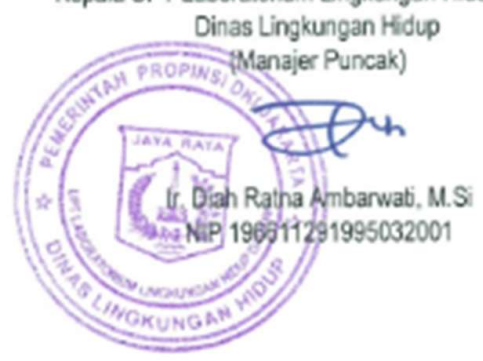




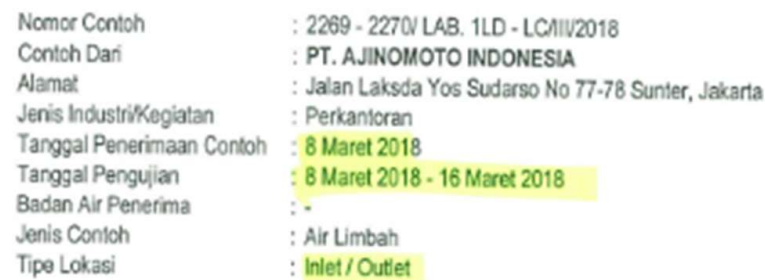

\begin{tabular}{|c|c|c|c|c|c|c|}
\hline \multirow{2}{*}{ No } & \multirow{2}{*}{ Parameter } & \multirow{2}{*}{ Satuan } & \multicolumn{2}{|c|}{ Hasi UT } & \multirow{2}{*}{ Kadar Maksimum } & \multirow[b]{2}{*}{ Metoda } \\
\hline & & & 2269 & 2270 & & \\
\hline 1 & pH & & 73 & 7.4 & 6.9 & SNI 06-6989.11-2004 \\
\hline 2 & Zat Padat Tersuspensi & $\mathrm{mgl}$ & 261.0 & 6.0 & 30 & Spektrobolometri \\
\hline 3 & Ammonia & $\mathrm{mgh}$ & 57.04 & 9.17 & 10 & No. 41/iKM (Segmented Flow Analysis) \\
\hline 4 & Minyak dan Lemak & $\mathrm{mgl}$ & 1.47 & $<0.54$ & 5 & Spekicrolosometri \\
\hline 5 & COD (Dichromat) & $\mathrm{mgh}$ & 453.09 & $<40.0$ & 100 & SNI 6969.73:2009 (Titrimevi) \\
\hline 6 & $800\left(20^{\circ} \mathrm{C}, 5\right.$ han $)$ & $\mathrm{mgl}$ & 56.48 & 4.73 & 30 & SNI 6969.72:2009 \\
\hline 7 & Total Coliform & Jumlah $100 \mathrm{~mL}$ & $\cdot$ & 0 & 3000 & No $401 k M$ (Petriflm) \\
\hline
\end{tabular}

Keterangan

2269 - iniet

2270 - Custer

$\rightarrow$ T) Tok Gonoliso

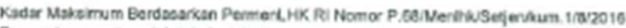

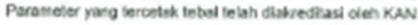

Jakarta, 22 maret 2018

Kepala UPT Laboratorium Lingkungan Hidup Daerah

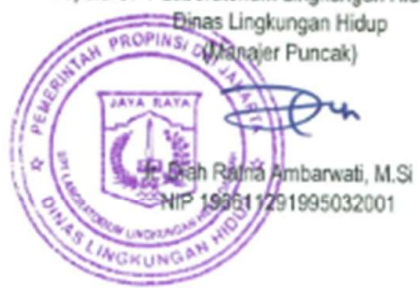

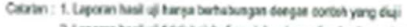

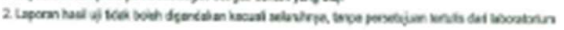




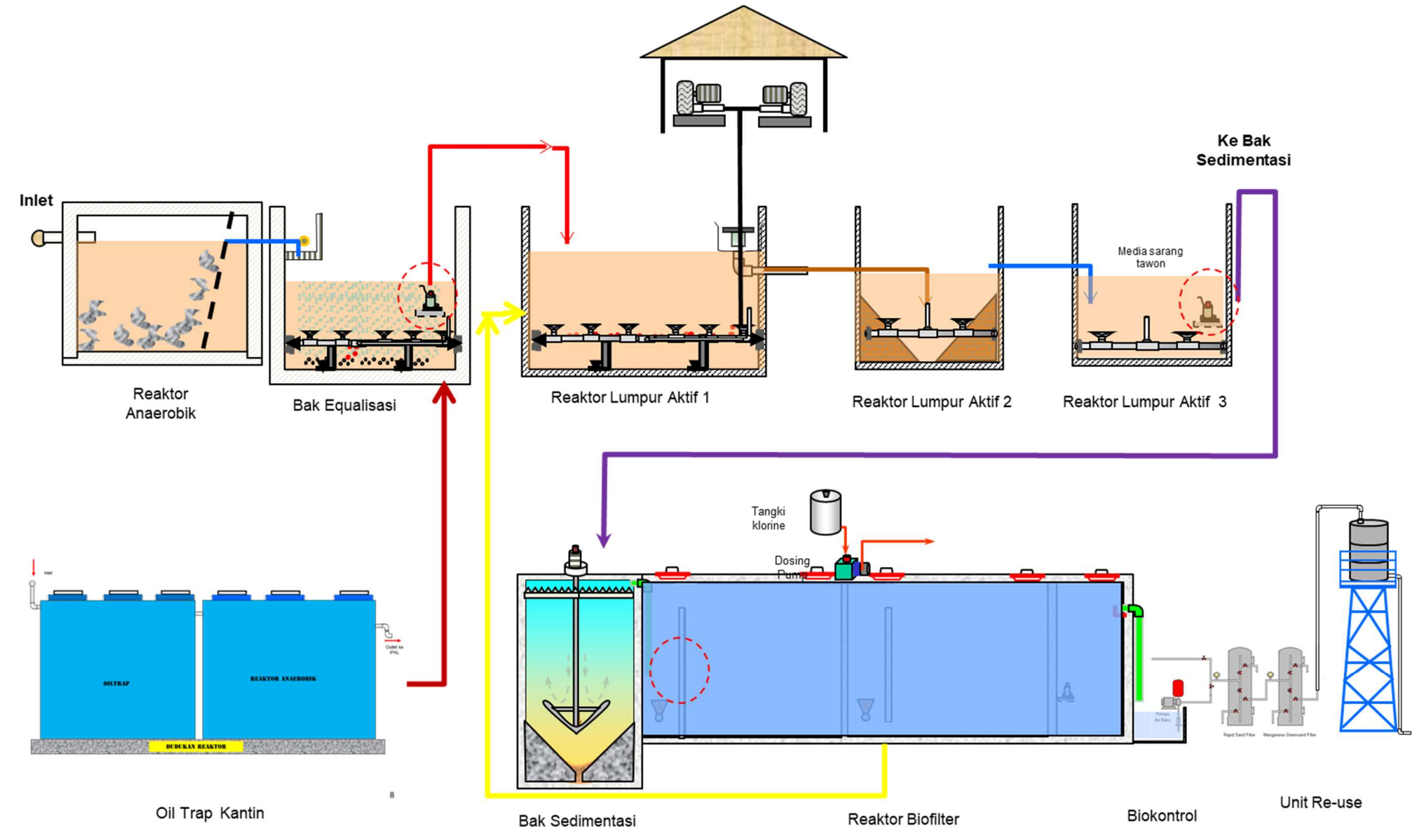

Gambar 18. Diagram alir proses pengolahan limbah domestik PT Ajinomoto Indonesia 